\title{
Gabriel Moser
}

24 March $1944-21$ April 2011

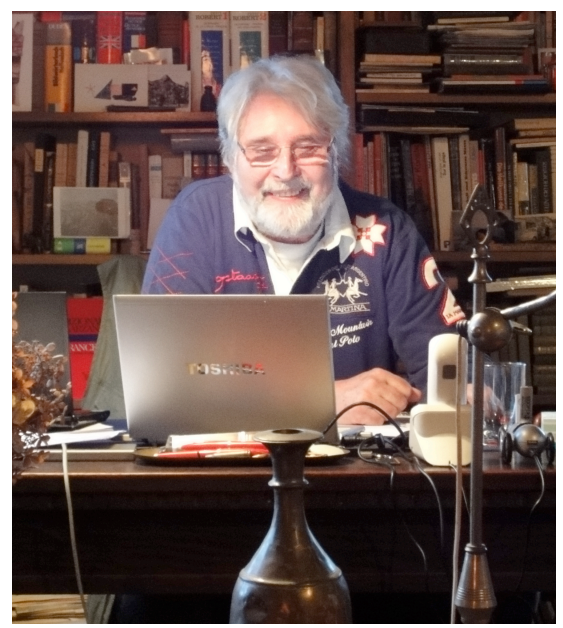

Gabriel Moser was born in Berne in Switzerland and is buried in Berne. Attachment to place was an essential part of Gabriel's personality as well as his academic interests. He was proud to be Swiss - visitors to his Paris apartment are greeted with a Swiss flag welcome mat. But despite his strong roots Gabriel was one of the most cosmopolitan and well-travelled people one could have the good fortune to meet. He spoke at least six languages and could 'get by' in several others including Japanese. His ability to communicate across cultures made him a good friend and colleague to many and an ambassador for environmental psychology across the world. In the tributes which poured in after the announcement of his death, it was his friendship, collegiality, and the very practical support he provided for nascent groups which were trying to establish environmental psychology in their countries, especially in Latin America, that was highlighted repeatedly.

Gabriel was born in March 1944, the son of Wilfrid Moser the highly influential Swiss artist of the post-war avant-garde. His father had studios in Paris, Zurich and Ronco (Switzerland) and Gabriel remained attached to these places throughout his life, keeping a house in each. Having studied for his License in Psychology in Switzerland, he moved to the Sorbonne where he was awarded all his subsequent degrees (DESS in Work Psychology; DESS in Clinical Psychology and Psychopathology; PhD in Social Psychology). He was offered a position as a lecturer in social psychology by Claude Lévy-Leboyer who was setting up a Laboratory of Applied Social Psychology at the Institute of Psychology at the Université Paris-Descartes; this was subsequently to become the CNRS Laboratory of Environmental Psychology. Lévy-Leboyer was an important influence on his work whether it was in terms of theory, methods or application. Two features of his early engagement with environmental psychology mirrored that of many other environmental psychologists. First, the research was in response to a real environmental problem that had been identified by the government and required both a policy and practical response. Second, he became 
fascinated by the fact that while the environmental stimulus may be constant, the perceived impact and response will be dependent on the relation of the individual to his/her home and to their overall satisfaction concerning their life conditions.

His early work was in the area of noise annoyance, and the results of these studies influenced his whole career insofar that they motivated him to do applied research and address socially relevant problems. This interest in noise led to a broader concern about perception and behaviour in respect of other environmental conditions reputed to be related to the quality of urban life. Progressively his interests broadened to examine a variety of behaviours in the urban environment, especially social interactions within the built environment consequent upon stress (e.g., aggression, vandalism and helping behaviour). Some of this work was brought together in the book he edited, Les stress urbains (Paris: Armand Colin, 1992). In one paper published in Environment and Behavior (with D. Corroyer, 2001) they posed the question, do high-density urban conditions lead to a reduction in civil behaviour and politeness? To test this they observed nearly 900 people entering department stores in Paris and Nantes to see whether they held the door open for those who followed. They found that Parisians were significantly less civil than their provincial counterparts, and high-density conditions reduced civil behaviour in both settings. It was an elegant study which sought to capture one small but significant characteristic of urban life. Through the 1990's and 2000's, Gabriel's work moved away from stress and focussed more on the appropriation of different urban spaces, interpersonal relationships in cities and most recently pro-environmental behaviour specifically related to water conservation and the contribution that environmental psychology could make to understanding our unsustainable lifestyles (Moser, G. \& Weiss K., Espaces de vie: Aspects de la relation homme-environnement. Paris: Armand Colin, 2003). He never forgot that Bruntland's model of sustainable development has an important social dimension, and will only be reached if due attention is given to issues such as place attachment, quality of life and citizenship.

In 1991, Gabriel was awarded the Doctorat ès Lettres et Sciences Humaines with a thesis on 'Environmental stress and urban behaviour'. In the following year he was appointed the first Professor of Environmental Psychology in France, and also the Director of the CNRS Laboratory of Environmental Psychology, a position he held until 2005. As Director, he established the DESS in Environmental Psychology which, along with an outstanding PhD programme, produced many of the leading environmental psychologists working in France and elsewhere today. He was the catalyst for environmental psychology research in France, which now flourishes in a number of French universities and coalesces around groups such as ARPenv.

Gabriel's contribution to the development and promotion of environmental psychology extended way beyond the borders of France. He played a crucial role internationally in 
encouraging and supporting researchers and fledgling research groups, especially in Latin America. He was particularly pleased that he could contribute to this through his publications in Spanish and Portuguese, the numerous contacts he forged with scholars especially in Brazil, Colombia, Chile and Mexico, and through organising, with others, several conferences. The last of these was in Sao Paulo in 2002 which attracted environmentbehaviour researchers from across Latin America and resulted in a Special Issue of Psicologia USP $(16,2005)$ on 'Psychology and the environment: The role of environmental psychology in the study of environmental questions'.

Gabriel made wise and constructive contributions to a number of international associations through his membership of the Executive Committee of IAAP (International Association of Applied Psychology), the Academy of Sciences of New York, and as Correspondent of the APA (American Psychological Association) for France, amongst others. But it was his commitment and enthusiasm in his work with IAPS (International Association for PeopleEnvironment Studies) where he had most impact. Gabriel organised IAPS16 in Paris in 2000 (Moser G., Pol E., et al Places, People \& Sustainability, Göttingen: Hogrefe, 2002) which was probably the most successful IAPS conference held, not only in terms of the numbers attending but in re-energising the Association. It provided a critical stimulus for a number of subsequent initiatives which brought together researchers from across the world, from different disciplines and at different stages in their careers. Gabriel was always keen to support the training and careers of young researchers. In the year in which he was elected as President of IAPS (2004-2008), the Young Researchers' Award scheme was introduced, which gives an award for the best early career researcher paper, and then later the Excellent Research Proposal Award. He always gave generously of his time, knowledge and experience, especially to students; this was so evident when he came to Guildford in his role of Visiting Professor at the University of Surrey. He actively developed the publications' policy of IAPS, and following the successful publication of some of the key thematic papers from the Paris (2002), La Coruña (2002) and Vienna (2004) IAPS conferences, he negotiated with Hogrefe Publishing a new book series entitled Advances in People-Environment Studies, which has published important papers from the subsequent Alexandria (2006) and Rome (2008) conferences.

Academics never really retire and Gabriel was no different. He continued to give lectures, attend conferences and write papers after he left the CNRS Laboratory. Over the last few years, he also applied his energy, imagination and resourcefulness to the establishment of the Stiftung/Fondation Wilfrid Moser which celebrates the artistic achievements of his father.

Gabriel was a warm, kind and generous person whose presence was life-affirming. He was great company with a wonderful sense of humour and any gathering around him was always a happy occasion. His personality was manifest in his physical stature. One has a strong 
image of him casually strolling down the street whatever the pressures of time; urban life was there to be enjoyed.

I remember having dinner with Gabriel and his wife, Dirce, in their Paris apartment when the topic of conversation turned to whether place attachment extended beyond life. In other words, how strongly do people feel about where they are buried and is where you are buried more or less important than with whom you are buried (e.g., one's partner). With characteristic energy a research project was underway within months. It is an irony that Gabriel would have enjoyed that one of his last published papers (with Casal and Aragonés, 2010) reported on this research and was entitled 'Attachment forever: environmental and social dimensions, temporal perspective, and choice of one's last resting place'.

He will be missed so much, in all places.

David Uzzell

University of Surrey

$27^{\text {th }}$ April 2011 